\title{
A PERCEPÇÃo AMBIENTAL E CLIMÁTICA DA POPULAÇÃO DE SÃO SEBASTIÃO DO CAÍ COMO FORMA DE PREVISÃO DE ENCHENTES NA BACIA HIDROGRÁFICA DO RIO CAÍ - RIO GRANDE DO SUL
}

\author{
Cássio Arthur Wollmann ${ }^{24}$ \\ Maria da Graça Barros Sartori ${ }^{25}$
}

\begin{abstract}
RESUMO
No Rio Grande do Sul, as enchentes se constituem em fenômenos naturais já conhecidos pela população, em especial, àquelas que habitam as vales dos principais rios sul-rio-grandenses. É nessa perspectiva que o objetivo geral desta pesquisa consistiu em avaliar, qualitativa e quantitativamente, a percepção ambiental e climática dos moradores ribeirinhos do meio urbano e rural do município de São Sebastião do Caí, a fim de que essa percepção/cognição ambiental permitisse prevenir desastres naturais; aplicando-se as metodologias de Whyte (1978) e Sartori (2000). Sobre essa percepção ambiental e climática como forma de prevenção de desastres naturais, contrariamente ao que se esperava, a população do meio urbano possui uma percepção e cognição ambiental e climática maior em relação à população do meio rural, em função de sofrer mais com as enchentes. Apenas as percepções relacionadas à observação do comportamento hídrico podem ser utilizadas como forma de previsão de enchentes e desastres naturais com algumas horas de antecedência em São Sebastião do Caí.
\end{abstract}

Palavras-chave: Enchentes; Rio Caí; Percepção Climática; Desastres Naturais.

\begin{abstract}
In Rio Grande do Sul, inundations are constituted in natural phenomena already known by the population, especially, those that inhabit the principal rivers valley in Rio Grande do Sul. So, the general objective of this research consisted in evaluated, qualitative and quantitative, the riverine residents' environmental perception of the urban and rural zone of the municipal district of São Sebastião do Caí, as a form to forecast the inundations, at municipal and regional level; Different methodologies were applied, especially Whyte (1978) and Sartori (2000). About the climatic perception as form of prevention of natural hazards, contrarily to the that was waited, the population of the urban zone possesses a
\end{abstract}

24 Geógrafo/UFSM-RS/Pós-Graduando Geografia Física USP - cassio_geo@yahoo.com.br.

25 Profa. Dra. /Depto. Geociências/UFSM-RS - magracas@smail.ufsm.br. 
perception and environmental and climatic cognition larger in relation to the population of the rural zone, in function of suffering more with the inundations. The perceptions related to the observation of the water behavior can just be used as form of forecast of inundations and natural disasters with some hours of antecedence in São Sebastião do Caí.

Key-words: Inundations; Caí River; Climatic Perception; Natural Hazards.

\section{INTRODUÇÃO}

A partir da década de 1970, a Ciência Geográfica mergulha em novo campo de pesquisas que, posteriormente, viria a descobrir uma das mais ricas abordagens ao correlacionar os saberes empíricos das populações com os saberes científicos: a percepção ambiental. Sartori (2000) esclarece que os primeiros estudos de percepção iniciam-se em função da ocorrência de paroxismos climáticos, como as enchentes no rio Mississipi (EUA).

Por percepção ambiental pode-se entender como o processo resultante da interação entre os sentidos humanos e os fenômenos ocorridos no meio ambiente capazes de produzir sensações psico-fisiológicas, criando um sistema de valores, atitudes e sensações do homem para com seu meio (Tuan, 1980; Machado, 1996; Sartori, 2000).

Dessa interação homem $X$ meio, que consiste na mais pura aplicabilidade do conceito de Ciência Geográfica ao se referir na apropriação do espaço sobre o homem e vice-versa, é que surgem diferentes formas de perceber, ou seja, cada pessoa percebe e entende o mundo a sua volta de uma forma muito pessoal e subjetiva. É o que TUAN (op. cit, p. 53) esclarece ao falar sobre os mundos perceptivos individuais, colocando que "para bem apreciar como podem variar as atitudes ambientais, necessitamos conhecer alguma coisa de fisiologia humana e da diversidade de temperamento... Idade, sexo, diferenças fisiológicas inatas e diferenças dentro de uma família".

Nesse sentido, a percepção ambiental é única e intransferível em cada ser humano, o que confere a cada indivíduo, um grau de significados, um juízo de valores (Tuan, op. cit.), que se estabelecem ao interceptar, através dos sentidos perceptivos, um dado fenômeno que esteja ocorrendo no espaço geográfico, tal como as enchentes.

O juízo de valor, portanto, nasce de experiências perceptuais, as quais Machado (op. cit.) julga-as em duas categorias: as positivas e as negativas. As experiências, cabe lembrar, podem ser percebidas através dos cinco sentidos humanos ao mesmo tempo, ou também por apenas um deles, ou ainda por mais de um. Assim, um juízo de valor pode mostrar-se diferente caso seja experimentado por sentidos diferentes.

Por exemplo, ver uma enchente pode significar um sentido de horror, ao passo que nadar em uma com o intuito de salvar os próprios bens, pode transformar-se, posteriormente, em trauma em relação á água de rio, como relatado por Buss, Furtado, Scheibe (2000) ao comentarem uma enxurrada no sudeste catarinense.

Outro ponto que pode influenciar no modo como o ser humano percebe o seu entorno, é o que Collot (1990) coloca como o "ponto de vista", a "parte" e o 
"conjunto". Para o autor, o "ponto de vista" pode ser entendido como o local a partir do qual o homem observa seu entorno, ambiente que cerca suas atividades cotidianas. A "parte" é considerada apenas a porção do meio que apenas um indivíduo enxerga, ou seja, cada pessoa vê apenas uma parte, reforçando o conceito de mundo perceptivo individual (Tuan, op. cit). Por fim, o "conjunto" traduz-se na totalidade da paisagem da qual a parte pertence e que é difícil ser percebida.

Conforme relatam Sartori (op. cit.), Oliveira (1996), Machado (op. cit.) e Tuan (op. cit.), após perceber, sentir e interpretar um fenômeno natural, o homem passa a estabelecer regras e relações entre suas percepções e a desenvolver a cognição, passando não mais a só perceber o fenômeno, mas também a conhecê-lo, ou seja, o estado de percepção ambiental passa para o de cognição ambiental. Segundo CLAUSSE (1973, p. 58) coloca que "primeiro, os homens aprenderam a observar os fenômenos para depois tentarem compreende-los, e em seguida procuraram, acumulando coincidências ou repetições, descobrir leis ou simplesmente regras de relacionamento desses fenômenos".

No que diz respeito à percepção e cognição climática, MARIANTE (1985 apud Wollmann; Sartori; Ruoso, et. al., 2006) coloca que:

Sem uma base cientifica que explicasse a dinâmica atmosférica e que sustentasse a sua previsibilidade, o ser humano, ao observar essa dinâmica, cria, inconscientemente, um "singular instituto meteorológico", o qual é enriquecido diariamente pela observação dos animais, plantas e elementos climáticos, e até mesmo das reações que seu próprio corpo por ventura sofre como as "dores meteotrópicas".

Assim, ao se analisar a percepção ambiental dos seres humanos, deve-se levar em conta variáveis individuais, tais como a idade, sexo, escolaridade, órgão do sentido mais apurado e local da paisagem a partir do qual interpreta o meio em que vive. A respeito desse ambiente no qual vive o individuo, MEGALE; FERNANDES (1984, p. 58), colocam que há "... dois tipos de ambientes humanos... os seres rurais e os seres urbanos. Em graus distintos de região para região, esses meios modelaram dois tipos de homens, com reações mentais e disposições fisiológicas diferentes".

Dessa forma, o modo de perceber e sentir o ambiente em que vive depende do tempo de vivência do indivíduo, seja no meio urbano, seja no rural.

No desenvolvimento mais contemporâneo da Ciência Geográfica, em especial abordagem Humanista, no qual se inserem os estudos de percepção ambiental, surgem em Sartori (2000) os primeiros estudos de Percepção Climática. Para a autora, o clima e os tipos de tempo em sua sucessão são capazes de influenciar psicológica e fisiologicamente sobre o ser humano, produzindo atitudes e sensações capazes de "prever" o tempo metereológico em curto prazo. Também são enfocados os estudos de percepção ambiental tanto no meio rural quanto no urbano. Nesse contexto, para SARTORI (2005, p. 1):

A percepção climática humana está fundamentada na percepção ambiental que certas pessoas desenvolvem, em maior ou menor grau, fruto da observação mais ou menos apurada, de fatos e fenômenos que ocorrem em seu entorno e que vêem, com o 
passar do tempo e a repetitividade, a se constituir em indícios, ou mesmo evidências, do comportamento da atmosfera a curto prazo.

Para tal, baseando-se em Tuan (1980), a relação do homem rural para com o seu ambiente é muito maior quando comparado ao citadino, pois convive diariamente com a terra e a natureza, extraindo-Ihe sua sobrevivência, e por isso, perceber e interpretar a natureza para ser questão de sobrevivência.

Sabe-se que as principais áreas agricultáveis do planeta estão localizadas em zonas de inundação e de enchentes. Desde a história Antiga, egípcios e mesopotâmios desenvolveram suas civilizações às margens de grandes rios e, observando o comportamento da natureza, aprenderam a prever os fenômenos naturais que davam origem às enchentes, muitas vezes observando os fenômenos celestes.

De acordo com MOURÃO (2003, p. 18):

No Egito, onde a agricultura dependia das enchentes e das vazantes do Rio Nilo, a aparição periódica das estrelas de determinadas constelações indicava os ciclos de inundação e estiagens..., e com isso, ... um conjunto de provérbios e ditos populares foram extraídos gradualmente, a partir de uma serie de sinais que eram considerados como uma indicação de futuras ocorrências.

Entretanto, no meio urbano, no qual a relação do homem com o meio natural é quase inexistente vista tamanha transformação do espaço natural pelo processo de urbanização, a percepção passa a ser menos apurada em relação a fenômenos naturais, como as enchentes, pois, as percepções ambientais e climáticas estão muito mais relacionadas aos impactos que as condições atmosféricas, em geral negativas, têm sobre as atividades espaciais humanas, conforme abordam Monteiro (1976) e Sartori (2000).

$\mathrm{Na}$ pesquisa realizada por Sánchez (1991), os impactos climáticos são muito mais vistos na cidade quando estes interferem no funcionamento das avenidas centrais. Já em relação aos rios, são relatados os aumentos no nível da água, trazendo transtornos a população ribeirinha.

Desse modo, fica evidente que no meio rural a percepção ambiental e climática é muito mais aguçada em comparação com o meio urbano, e no caso de percepção de enchentes como uma forma de previsão meteorológica a curto prazo, o homem rural pode-se tornar um competente previsor de desastres ambientais. Conforme relatou Sartori (2005) e Wollmann; Sartori; Ruoso, et. al. (2006), alguns métodos de previsão de tempo do homem rural podem ser capazes de predizer as condições atmosféricas a curtos e médios prazos.

Sendo assim, a percepção ambiental e climática como forma de prevenção de desastres ambientais, pode se tornar uma exímia ferramenta de prevenção de impactos causados pelas enchentes, tanto no meio urbano, quanto no meio rural, especialmente neste último, fruto do aprimoramento percepto-cognitivo do homem do campo. No caso do homem rural sul-riograndense, que tem sua percepção climática apurada, conforme relata Sartori (2000, 2005) em sua pesquisa, as enchentes, comuns no Estado, podem vir a ser "previstas" com certa antecedência, minimizando possíveis perdas humanas e materiais e danos ambientais com a chegada da enchente. 
A previsão de enchentes através da percepção, bem como de outros desastres naturais, tem ganhado devido o respeito nos últimos anos, até mesmo na elaboração de Planos Diretores municipais, pois conforme o MINISTÉRIO DAS CIDADES (2001, p. 110):

Avaliar a percepção de risco natural e forma de organização social para enfrentar situações de crise durante eventos catastróficos são elementos importantes para subsidiar a escolha de alternativas de redução de riscos. São também relevantes para conceber e implantar planos de contingência e de gestão de crise.

Assim, esta pesquisa teve como objetivo geral a proposta de avaliar, qualitativa e quantitativamente, a percepção ambiental e climática dos moradores ribeirinhos do meio urbano e rural do município de São Sebastião do Caí, Rio Grande do Sul, a fim de que essa percepção/cognição ambiental seja capaz de prevenir desastres naturais, como as enchentes, a nível municipal e regional;

\section{LOCALIZAÇÃo DA ÁREA DE ESTUDO}

O município de São Sebastião do Caí (Latitude $-29^{\circ} 35^{\prime}$ e Longitude $51^{\circ}$ $26^{\prime}$ W) está localizado no vale do rio de mesmo nome (Figura 03). Possui uma população de 22.413 habitantes, conforme IBGE (2007), sendo que $81 \%$ (18.154 habitantes) moram no meio urbano e 19\% (4.259 habitantes) vivem no meio rural. O processo de colonização da região data do início do século XIX, com a chegada dos imigrantes alemães, entretanto, a cidade foi fundada por portugueses em $1^{\circ}$ de maio de 1875 , mas colonizada pelos alemães que já viviam em seu território. São Sebastião do Caí originou-se em função da construção do Cais do Porto (Figura 01), pois era o local mais adequado do trecho navegável do Rio Caí com finalidade para escoar a produção rural regional para Porto Alegre através de embarcações a vapor, em viagens que duravam até três dias para percorrer 65 quilômetros.

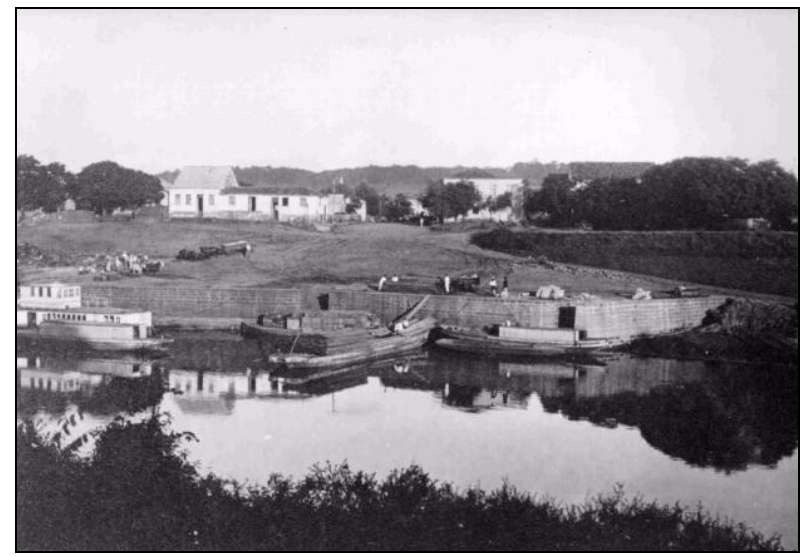

Figura 01 - Cais do Porto em São Sebastião do Caí no início do século XX. Fonte: Museu Histórico Municipal de São Sebastião do Caí, 2007. 
A economia municipal baseia-se nos três setores, sendo um dos municípios com economia mais diversificada do Vale do Caí, bem como do Rio Grande do Sul. Atualmente, o Município possui sua área rural dividida em 7 (sete) distritos rurais: Várzea, Vigia, Chapadão, Lajeadinho, Campestre, Tafona e Pareci Velho; 2 (duas) aglomerações urbanas: Conceição e Areião; e 1 (uma) sede municipal, que esta dividida em 7 bairros: Centro, Navegantes, Quilombo, Angico, Vila Rica, Progresso e Rio Branco.

No que se refere às características geoambientais de São Sebastião do Caí, o município pertence ao tipo de clima Cfa, segundo Köppen (apud Ayoade, 2003) que domina na maior parte do Estado, ainda apresenta chuvas bem distribuídas ao longo do ano, com média anual em torno de $1482 \mathrm{~mm}$, correspondendo, em média, a 105 dias do ano com presença de chuva. As temperaturas médias durante o verão variam entre $25^{\circ}$ e $35^{\circ}$ e no inverno oscilam entre $12^{\circ}$ e $25^{\circ}$ (CEF; ENNH, 2000).

O relevo do município insere-se em duas compartimentações geomorfológicas presentes no Rio Grande do Sul: a Depressão Periférica sul-riograndense, localizada na parte oeste e sul do Município; e o Planalto da Bacia do Paraná, cujos morros testemunhos oriundos das escarpas do rebordo do planalto são marcas na paisagem municipal. As rochas que modelam mo relevo em nível municipal são as rochas areníticas da Formação Botucatu, as rochas vulcânicas da Formação Serra Geral, com a presença de diques e sedimentares e rochas sedimentares do período Quaternário, que correspondem às áreas de várzea do Município.

A altimetria de São Sebastião do Caí varia poucas dezenas de metros, desde altitudes de 15 metros acima do nível do mar, na várzea do Rio Caí, até altitudes de 200 metros, no topo dos morros testemunhos do Planalto da Bacia do Paraná. Nesse sentido, destacando-se a presença de inúmeros morros testemunhos no cenário caiense, como o Morro da Vigia (234m), o Morro da Conceição (165m), o Morro de São Rafael (101m), o Morro do Martim (117m), o Morro do Pareci Velho (121m) e o Morro dos Berwanger (72m).

\section{MATERIAIS E MÉTODOS}

As formas de investigação da percepção das pessoas que tenham vivenciado determinados fenômenos naturais não são fáceis de encontrar nos estudos de diversos autores, são aplicadas, obviamente, à realidade pessoal de cada área de estudo e objetivos de trabalho

Nesse sentido, ao saber que os trabalhos de percepção ambiental e climática para o Rio Grande do Sul restringem-se aos de Sartori (2000; 2003; 2005), e que a referida autora baseou-se em Whyte (1978) para investigar e avaliar qualitativa e quantitativamente a percepção climática da população da região central do Estado como forma de previsão do tempo a curto prazo a partir de ditados de previsão meteorológica, buscou-se com isso, a percepção da população como forma de prevenção de desastres naturais decorridos de enchentes no Rio Grande do Sul, utilizando-se o triângulo metodológico de Whyte (op. cit., p.21), conforme mostra a Figura 02: 


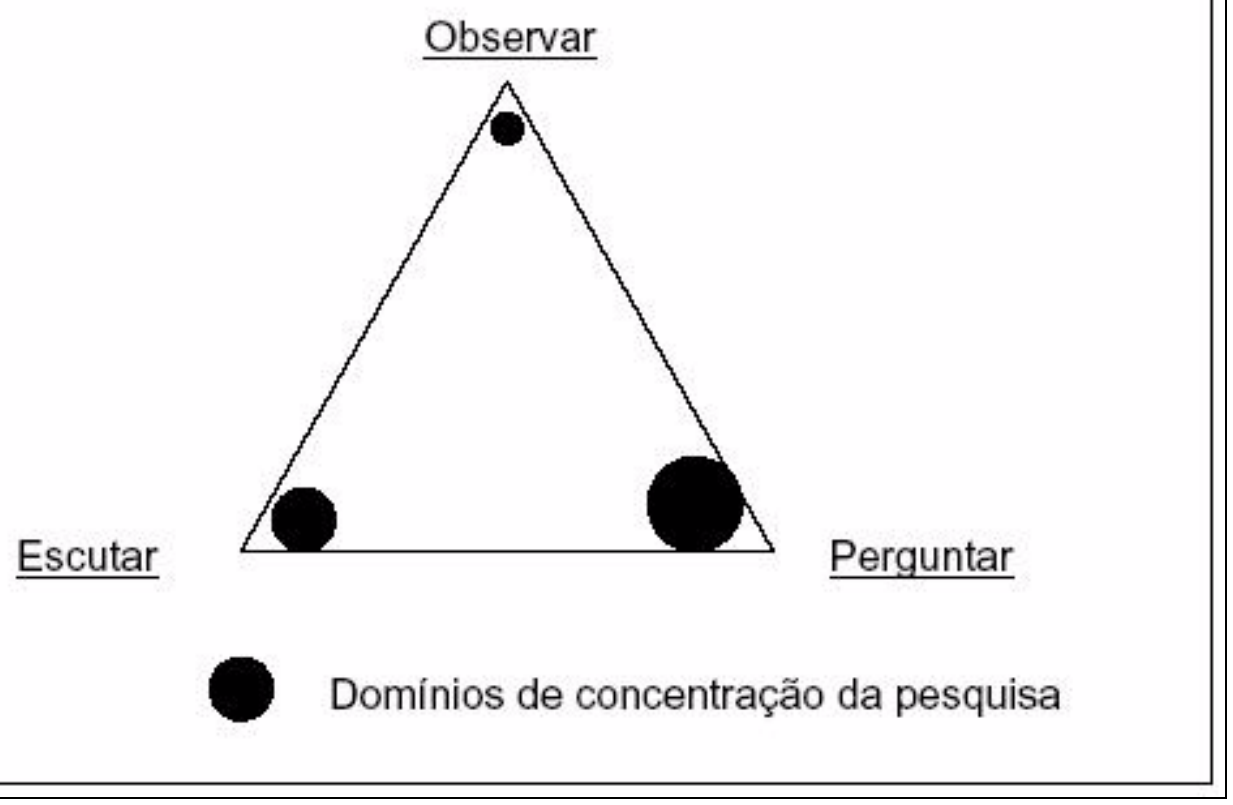

Figura 02 - Triângulo Metodológico de Whyte, para pesquisas envolvendo a investigação da percepção do meio ambiente pela população a ser entrevistada.

Fonte: WHYTE (1978, p. 21)

Org.: WOLLMANN, C. A., 2007.

Para Whyte (op. cit.), certas técnicas de pesquisa manifestam o complexo mundo que é o das ciências interdisciplinares. Neste contexto, é que se insere a percepção ambiental como uma das tendências de pesquisa da Geografia, e também da Climatologia Geográfica, como aprofundado em Sartori (2000).

Assim, investigar a ocorrência de enchentes através da percepção ambiental e climática da população urbana e rural de São Sebastião do Caí torna-se fato quando esta população já sofreu várias vezes com este fenômeno. Dessa forma, o triângulo metodológico serviu para a análise posterior desta percepção.

O triângulo consiste em três métodos de pesquisa em percepção do meio ambiente: o perguntando, o ouvindo e o registrando e o observando. O primeiro consiste em aplicação de formulários de perguntas para ser usado em entrevistas; o segundo método consiste em o pesquisador ouvir e registrar, após questão desencadeadora, o que o entrevistado tem a dizer sobre o tema; o terceiro, do observando, desenvolve-se a partir da observação pelo pesquisador do comportamento das pessoas frente ao fenômeno ou fato estudado.

Deste modo, utilizou-se como método o "perguntando", cujo questionário de entrevistas foi aplicado junto à população ribeirinha do meio rural e urbano de São Sebastião do Caí/RS entre os dias 17 e 19 de maio de 2007, no qual se buscou avaliar qualitativa e quantitativamente a percepção ambiental dessa população como forma de prevenção de desastres naturais decorridos das enchentes no espaço geográfico caiense. 
Com a aplicação das primeiras questões do formulário de entrevistas, tais como a idade, sexo e tempo de residência no local, dentre outras, conforme já afirmou Tuan (op. cit.), pretendeu-se buscar as interferências no processo percepto-cognitivo ambiental do entrevistado a respeito das enchentes em São Sebastião do Caí e a influência de seu juízo de valor sobre a percepção deste fenômeno na Bacia Hidrográfica do rio de mesmo nome.

Com a aplicação das questões 1 a 4, pretendeu-se inserir o entrevistado no contexto das enchentes, uma vez que o tempo de ocorrência de enchentes pode ter se dado há alguns anos, logo há um relativo "esquecimento" sobre o fenômeno quando este não se apresenta cotidianamente ao entrevistado, mas apenas alternados e/ou episódicos. Assim, relembrá-lo das dificuldades enfrentadas em tempo de enchente, aflorou-lhe as sensações e percepções a cerca da temática proposta com esta metodologia.

Por fim, a questão de número 5 (cinco) é a que permitiu avaliar as formas de previsão de enchentes a partir da percepção ambiental e climática dos moradores ribeirinhos de São Sebastião do Caí, o que será discutido no decorrer deste trabalho.

\section{RESULTADOS E DISCUSSÕES}

A partir do momento em que se buscou trabalhar sobre a percepção ambiental e climática da população de São Sebastião do Caí a respeito das enchentes na Bacia Hidrográfica do Rio Caí foi com o intuito de se encontrar uma forma de prevenção contra desastres naturais e de redução dos prejuízos no Município, buscando-se delimitar exatamente o que seria perguntado a essa população, bem como onde vive.

Nesse sentido, para obterem-se diferentes visões, e depois compará-las, a respeito das enchentes, procurou-se entrevistar tanto a população urbana quanto a rural. Na seleção dos bairros e distritos rurais, optou-se por aqueles que já possuíssem um histórico de ocorrência de enchentes, tais como Quilombo, Navegantes, Centro e Vila Rica.

Para os distritos rurais, apenas dois são atingidos pelas enchentes: Várzea e Pareci Velho. Entretanto, optou-se por entrevistar a população residente apenas no distrito da Várzea, por este localizar-se a norte da área urbana, pois o Rio Caí, com orientação aproximadamente norte-sul, obrigatoriamente passa pelo referido distrito antes de chegar na cidade. Assim, a população rural residente na Várzea pode prevenir a população urbana sobre o escoamento das águas superficiais, para minimizar os possíveis prejuízos, pois, conforme Sánchez (1991) é no meio urbano que são registradas as maiores repercussões socioeconômicas e ambientais.

Para o distrito do Pareci Velho, localizado a sul da área urbana, e atingido pela enchente após já ter percorrido as áreas urbanas e rurais (Várzea), considerou-se que a percepção de seus moradores sobre as enchentes não apresentaria um caráter preventivo à área urbana. Entretanto, não se descartam os saberes empíricos desta população. Sendo assim, a percepção sobre as enchentes dos moradores do Pareci Velho pode motivar investigações futuras.

Depois de selecionada a população, partiu-se para as entrevistas com aplicação de questionário com perguntas abertas e fechadas nos referidos 
bairros e distrito rural, que ocorreram entre os dias 17 e 19 de maio de 2007, cujo trajeto percorrido pode ser melhor ser visualizado no esboço cartográfico da Figura 03.

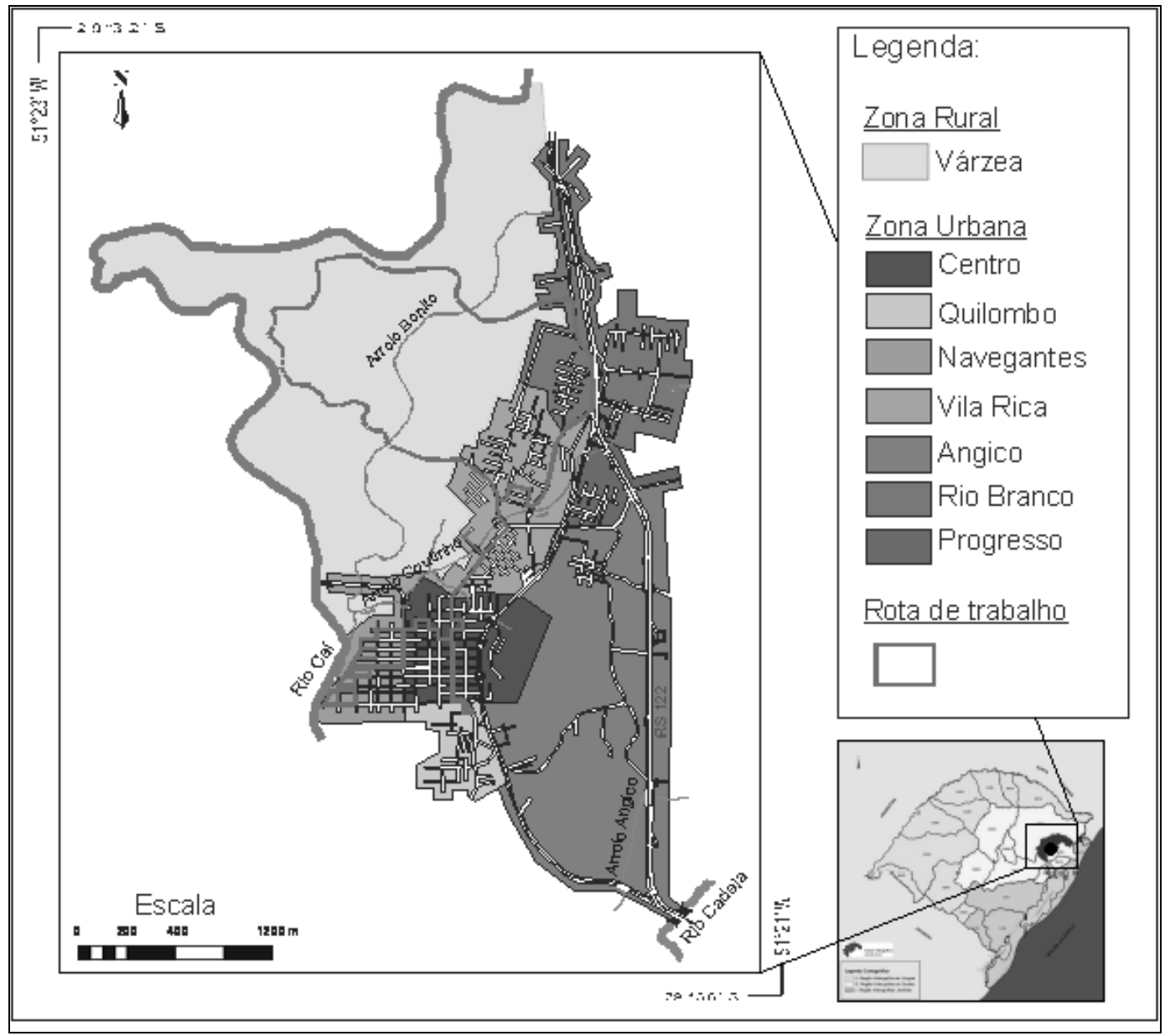

Figura 03: Rota de trabalho de campo realizada para levantamento da percepção ambiental e climática das enchentes do Rio Caí. Município de São Sebastião do Caí/RS.

Org.: WOLLMANN, C. A., 2007.

Procurou-se entrevistar um total de 50 pessoas, pois sendo entrevistados em local-chave de ocorrência de enchentes, poderia refletir a percepção ambiental e climática sobre as enchentes que atingem o Município. Desse total, $30 \%$ (15 pessoas) foram entrevistadas no meio rural e $70 \%$ (35 pessoas) no meio urbano. Segundo o IBGE (2006), 20\% da população se São Sebastião do Caí reside no meio rural, contra $80 \%$ no urbano. Portanto, decidiu-se equilibrar esses valores sobre o total de questionários aplicados entre as duas zonas do município, porém, elevando-se um pouco o número de entrevistas no meio rural, pois este poderia revelar percepções sobre as enchentes mais ricas em relação à população da cidade, conforme discutido na revisão teórica.

Assim, para melhor compreender os dados coletados a partir das entrevistas realizadas com o instrumento de pesquisa, dividiu-se esta etapa de 
análise entre o meio rural e o meio urbano, a fim de melhor distinguir suas percepções no que se refere à gênese das enchentes do Rio Caí.

\section{Da população rural}

Após levantadas as informações contidas na parte inicial do instrumento de pesquisa utilizado, constatou-se que foram entrevistados, de um total de 15 pessoas, 8 mulheres $(53,3 \%)$ e 7 homens $(46,7 \%)$. Desse total, 4 possuíam idade entre 18 e 35 anos (26,7\%), 7 pessoas tinham idade entre 36 e 50 anos $(46,7 \%), 3$ pessoas com idade entre 51 e 65 anos $(20,0 \%)$ e apenas uma pessoa com idade superior a 66 anos, perfazendo $6,7 \%$ do total.

Quanto às atividades exercidas pelos entrevistados, 4 declararam ser pequenos agricultores (26,9\%), 3 aposentados $(20,0 \%)$, e duas donas-de-casa $(13,2 \%)$. Os demais entrevistados possuíam atividades das mais variadas: 1 mecânico $(6,7 \%), 1$ foguista de olaria $(6,7 \%), 1$ estudante $(6,7 \%), 1$ autônomo $(6,7 \%)$, e 2 desempregados $(13,2 \%)$.

Sobre sua naturalidade, 12 pessoas afirmaram ser naturais de São Sebastião do Caí, correspondendo a $80 \%$ dos entrevistados, sendo que estas mesmas pessoas declararam residir no distrito de Várzea desde o nascimento. Esta característica pode indicar um alto nível de percepção ambiental pela população rural quanto à gênese das enchentes. As outras 3 pessoas $(20 \%)$ afirmaram ser naturais de outros municípios do Vale do Caí, residindo no local menos de 10 anos, mesmo assim, já enfrentou enchentes ou conhece o fato, pois são naturais da região.

Quando perguntado a questão desencadeadora de número 1, 13 pessoas $(86,7 \%)$ declararam ter tido suas residências invadidas por enchente, sendo que 2 entrevistados $(13,3 \%)$ declararam ter água apenas no pátio, não adentrando a residência.

Dentre as maiores enchentes citadas, conforme perguntado na questão de número 2, a enchente de 1982 foi citada 7 vezes; a de 2000, 14 vezes, e a de 2001 apenas uma vez, perfazendo 31,8\%, 63,6\% e 4,6\%, respectivamente. Cabe ressaltar que nesta questão, o entrevistado poderia sugerir mais de uma enchente conforme fosse lembrando.

As questões de número 3 e 4 referiam-se aos tipos de prejuízos deixados pelas enchentes. Quando perguntado se haviam tido algum tipo de prejuízo em suas residências ou com familiares, 8 pessoas $(53,3 \%)$ responderam não terem tido prejuízos desta natureza, há exceção do barro e sujeira deixado pela enchente. Dentre os tipos de prejuízos mais comuns enfocados pela população, estão os listados na Tabela 01.

Muitos dos prejuízos referem-se às perdas recíprocas da produção rural, tal como morte de animais e inundação de plantações. Quando finalmente foi perguntada a questão desencadeadora de número 5 , que revelaria a percepção ambiental e climática da população sobre as enchentes, várias observações foram anotadas, pois muitas pessoas, às vezes, diziam várias observações em relação à enchentes, uma vez que, com esta pergunta, o entrevistado tinha liberdade de expressar suas percepções sem interrupção do entrevistador, atendendo à metodologia proposta com o triângulo de Whyte (1978).

Entretanto, ao computar-se estas informações, deparou-se com diferentes tipos de percepções no que se refere ao que era, de fato, observado 
pelo entrevistado antes da ocorrência de uma enchente. Nesse sentido, as percepções anotadas no meio rural puderam ser classificadas e agrupadas em três grupos de percepções: as relacionadas à observação do escoamento das águas superficiais; as relacionadas à observação da dinâmica atmosférica e as relacionadas às informações passadas entre a população local e intermunicipal.

Tabela 01 - Tipos de prejuízos mais comuns ressaltados pela população rural do Distrito da Várzea em casos de enchentes

\begin{tabular}{lcc}
\hline \multicolumn{1}{c}{ Prejuízo relatado } & $\mathbf{N}^{\circ}$ de citações & Porcentagem (\%) \\
\hline Móveis & 6 & 30,0 \\
\hline Pomares de frutas & 2 & 10,0 \\
\hline Pastagens/gado & 2 & 10,0 \\
\hline Plantações de flores & 2 & 10,0 \\
\hline Galinhas & 1 & 5,0 \\
\hline Hortaliças & 1 & 5,0 \\
\hline Caixas de abelhas & 1 & 5,0 \\
\hline Eletrodomésticos & 1 & 5,0 \\
\hline Documentos & 1 & 5,0 \\
\hline Madeira de eucalipto & 1 & 5,0 \\
\hline Sem ajuda da prefeitura & 1 & 5,0 \\
\hline Água levou a casa & 1 & 5,0 \\
\hline \hline Total & $\mathbf{2 0}$ & $\mathbf{1 0 0}$ \\
\hline
\end{tabular}

Fonte: Trabalho de Campo, 2007.

Org.: WOLLMANN, C. A., 2007.

Assim, a Tabela 02 mostra as percepções relacionadas à observação do escoamento das águas superficiais, coletadas junto aos moradores do distrito rural de Várzea.

Tabela 02 - Percepção das enchentes pela população rural do Distrito da Várzea relacionada à observação do escoamento das águas superficiais.

\begin{tabular}{lcc}
\hline \multicolumn{1}{c}{ Percepções coletadas } & $\mathbf{n}$ & $\mathbf{\%}$ \\
\hline "Se baixar a enchente rápido demais, chove de novo e vem outra" & 3 & 25,0 \\
\hline Arroios "sobem ao contrário" & 2 & 16,9 \\
\hline "Se a enchente bater embaixo da ponte da BR 116, vai ser grande" & 1 & 8,3 \\
\hline $\begin{array}{l}\text { "Se o rio subir 3m na Várzea, ele sobe no bairro Navegantes em } \\
\text { 7h". }\end{array}$ & 1 & 8,3 \\
\hline Arroio Bonito sobe na estrada & 1 & 8,3 \\
\hline "Se o rio está baixo, e chover muito, não dá enchente" & 1 & 8,3 \\
\hline "Quando o Rio Cadeia tranca o Rio Caí, sinal de enchente" & 1 & 8,3 \\
\hline "A enchente é traiçoeira, vem de noite, como ladrão" & 1 & 8,3 \\
\hline A enchente começa no Vale Real & 1 & 8,3 \\
\hline \hline Total & $\mathbf{1 2}$ & $\mathbf{1 0 0}$ \\
\hline
\end{tabular}

Fonte: Trabalho de Campo, 2007.

Org.: WOLLMANN, C. A., 2007. 
De acordo com a Tabela 02, doze percepções foram coletadas em relação à observação do escoamento das águas superficiais. Destas, 3 (25,0\%) dizem que "se a enchente baixar rápido demais, chove de novo e vem outra". Conforme as análises climáticas de Wollmann (2008) ficou comprovado que uma enchente não acontece logo após a passagem de uma outra. Provavelmente, o medo deixado por uma grande enchente, cuja rápida vazão provoca mais prejuízos, deixa a população apreensiva e com medo de outra enchente.

Com duas colocações $(16,9 \%)$, a população referiu-se ao fato de que os "arroios sobem ao contrário". Na verdade, o que ocorre não é a inversão do fluxo de água em um dado arroio, mas sim, por estes localizarem-se em áreas topograficamente mais rebaixadas e por se constituírem nos tributários de ordens inferiores ao canal principal (Rio Caí), quando este aumenta seu nível em função de uma enchente, é através dos arroios que a água começa a subir após extravasar o canal principal, dando a impressão de inversão do fluxo de escoamento.

Com 1 observação ( $8,3 \%)$, a população colocou que "se a enchente bater embaixo da ponte da BR 116, vai ser grande" significa que, empiricamente, a população associou a altura da ponte à altura que a enchente pode atingir em São Sebastião do Caí, utilizando-a como espécie de nível para a coluna de água do rio. A saber, a ponte sobre a BR 116 localiza-se no município de Vale Real, distante 30 quilômetros de São Sebastião do Caí na direção Nordeste, e está situada em um vale estreito onde o rio começa a percorrer áreas de menor declividade, cuja ausência de várzeas faz o rio subir rapidamente, podendo atingir a base da ponte.

Também, com 1 observação (8,3\% do total de observações levantadas), o entrevistado do meio rural destacou que "se o rio subir 3 metros na Várzea, ele sobre no bairro Navegantes em 7 horas". Nessa observação, empiricamente, a população calculou o tempo gasto pela enchente para passar do meio rural para o urbano, cuja distância seria de aproximadamente 10 quilômetros. Essa informação torna-se valiosa, pois com uma antecedência de 7 horas, a população do meio urbano pode se precaver e mover seus pertences para áreas mais altas, diminuindo os prejuízos caso não fossem avisados com antecedência ${ }^{26}$.

Com 1 observação (8,3\%), o entrevistado coloca que em uma enchente, o "Arroio Bonito sobe na estrada". Conforme o mapa da Figura 02, este arroio nasce no bairro Rio Branco, atravessa o distrito da Várzea e desemboca no Rio Caí no bairro Navegantes, na área urbana. Entretanto, a partir do momento no qual o Arroio Bonito sobe na estrada, a enchente já alcançou níveis capazes de atingir considerável parte do meio urbano, não se constituindo em uma ferramenta de previsão de enchentes, pois a enchente, neste momento, já é fato.

Também foi colocado, com 1 observação $(8,3 \%)$ que "se o rio está baixo, e chover muito, não dá enchente". Nesse caso, como o leito do rio está raso em função de períodos de estiagem, mesmo que chova o suficiente para ocorrer uma enchente, não acaba ocorrendo, pois muita água fica, em um primeiro momento, retida no solo através do escoamento sub-superficial, e em um

\footnotetext{
${ }^{26}$ De fato, a população do distrito da Várzea avisa a população urbana através da queima de fogos de artifício. Há um código: a cada fogo de artifício estourado (que produz apenas barulho), significa que enchente aumentou em 1 metro na Várzea. Assim, a Defesa Civil Municipal é capaz de calcular a altura da água que atingirá a área urbana de São Sebastião do Caí e em quanto tempo.
}

118

Ano 6 - Volume 6 - Junho/ 2010 
segundo momento, passaria a encher o rio propriamente dito. Assim, muita água fica retida no subsolo, diminuindo o que iria parar no rio. Nesse caso, seria necessário chover muito mais para que compensasse a escassez de água inicial e para gerar uma enchente de proporções habituais no Rio Caí.

Em 1 caso $(8,3 \%)$ foi colocado que "quando o Rio Cadeia tranca o Rio Caí, é sinal de enchente". De acordo com o perfil longitudinal do Rio Cadeia e do Rio Caí contidos em Wollmann (2008), percebe-se que o comprimento do primeiro é inferior ao do segundo rio, entretanto ambos nascem no topo do Planalto da Bacia do Paraná. Assim, a chuva precipitada na Serra chegaria muita mais rápida pelo Rio Cadeia em comparação com o Rio Caí, dada menor distância a ser percorrida pela água. Desse modo, a vazão no Rio Cadeia aumentaria consideravelmente em sua foz, barrando o fluxo que desceria pelo Rio Caí, fazendo-o elevar-se lentamente, sendo percebido ao longo de toda sua extensão no Município, anunciando que o Rio Cadeia subiu, e que grande quantidade de água descerá pelo Rio Caí nos próximos dias, podendo ocorrer enchente.

Em 1 observação $(8,3 \%)$ foi colocado que "a enchente é traiçoeira, vem de noite, como ladrão". Na realidade não há relação entre o horário do dia e a saída de água do leito do rio para as várzeas, conforme mostraram decretos de calamidade pública municipais consultados, e que contêm o horário no qual foi feita a medição da cota máxima de água em São Sebastião do Caí.

Acredita-se que o medo provocado por uma enchente aumente durante a noite em função de que a noite é vista, pela maioria das pessoas, como misteriosa e fonte de perigos. Também durante a noite a companhia de distribuição e abastecimento de energia elétrica desliga a energia elétrica em vários bairros do município a fim de que não ocorram curtos circuitos, incêndios e choques elétricos, pois a água, muitas vezes, atinge altura suficiente de postes de energia e transformadores residenciais, deixando a população no escuro, o que pode aumentar o medo da população em relação à chegada da enchente.

Por fim, ainda foi colocado por um entrevistado $(8,3 \%)$ que "a enchente começa no Vale Real". Conforme colocado anteriormente, no município de Vale Real, mesmo estando o rio situado em um vale encaixado, é quando este começa a percorrer terrenos com menor declividade, e a montante deste município, vários tributários do Rio Caí já desembocaram, aumentando a massa de água no canal principal. Assim, neste Município, percebe-se o início da enchente.

A Tabela 03, por sua vez, mostra a percepção rural em relação à observação da dinâmica atmosférica responsável pela gênese das enchentes na Bacia Hidrográfica do Rio Caí.

De acordo com a Tabela 03, das 17 observações declaradas, 8 delas $(47,1 \%$ do total) referem-se ao fato de que deve chover muito na serra e ou cabeceiras dos rios. Tal fato mostra que a população reconhece que a chuva que precipita em São Sebastião do Caí não é a responsável pela gênese das enchentes, mas sim a que precipita nas nascentes dos vários tributários do Rio Caí, que descem o rebordo do planalto, somando-se e formando a enchente.

Em outras 7 observações $(41,1 \%)$ foi dito que é muito difícil saber, ou não sabem, prever quando ocorrerá uma enchente. De acordo com Wollmann (2008), os tipos de sucessão do tempo responsáveis por enchentes são comuns 
e podem acontecer em qualquer época do ano, entretanto, em alguns casos, conforme já estudado, podem gerar enchentes.

Tabela 03 - Percepção das enchentes pela população rural do Distrito da Várzea relacionada à observação da dinâmica atmosférica.

\begin{tabular}{lccc}
\hline \multicolumn{1}{c}{ Percepções coletadas } & $\mathbf{n}$ & $\mathbf{\%}$ \\
\hline Chove muito na Serra/cabeceiras & 8 & 47,1 \\
\hline Não sabe/muito difícil prever & 7 & 41,1 \\
\hline Chove muitos dias seguidos & 1 & 5,9 \\
\hline De 10 em 10 anos dá uma enchente grande & 1 & 5,9 \\
\hline \hline Total & $\mathbf{1 7}$ & $\mathbf{1 0 0}$ \\
\hline
\end{tabular}

Fonte: Trabalho de Campo, 2007.

Org.: WOLLMANN, C. A., 2007.

Ainda, 1 pessoa (5,9\% do total de observações) afirmou ser necessário chover vários dias seguidos para que ocorra uma enchente. Nesse caso, pode-se tratar da percepção climática a cerca da participação de uma frente estacionária sobre o Rio Grande do Sul, e que pode permanecer vários dias, provocando chuva e elevando os índices pluviométricos sobre o planalto, podendo levar à ocorrência de enchente.

Por fim, 1 observação $(5,9 \%)$ foi feita em relação à periodicidade de uma grande enchente: 10 em 10 anos. A saber, foram registrados 16 casos de enchentes no período de 24 anos analisados (1982-2005), sendo que todas elas atingiram níveis superiores a 10 metros. Nesse caso, a percepção não se confirma, pois, mesmo que sejam considerados apenas os dois casos de maiores enchentes: junho de 1982 e outubro de 2000, com 14 e 14,75 metros de altura, há um intervalo de 18 anos entre as mesmas, praticamente duas vezes mais do que o relatado pelo entrevistado, tornando inválida esta afirmação.

Entretanto, é sabido que a memória é seletiva. Assim, o entrevistado, mesmo não tendo consciência do intervalo mais ou menos exato, em anos, entre as maiores enchentes, infere um resultado ao qual considera ser o adequado entre os dois casos extremos de enchente em São Sebastião do Caí.

Já a Tabela 04 mostra a percepção relacionada às informações passadas entre a população local e intermunicipal sobre as enchentes e suas repercussões.

De um total de 4 observações, de acordo com a Tabela 04, 2 (duas) pessoas ( $50 \%$ do total) declararam acompanhar a ocorrência de enchentes pelo noticiário/mídia. Todavia, ressalta-se que a mídia trata do fato quando este está acontecendo, e não como forma de previsão. Nesse sentido, a mídia não tem uma função de prevenção, mas apenas de informação do fato.

Ainda, 1 entrevistado (25\%) colocou o fato de amigos passarem informações de cidade em cidade avisando o que está acontecendo que amigos residentes em outras cidades à montante da bacia hidrográfica avisam a real situação em seus municípios. Neste caso, o fato de amigos passarem informações de cidade em cidade avisando o que está acontecendo em tempo real pode se tornar uma forma de prevenção de calamidade, uma vez que 
alertaria, com horas de antecedência, a chegada de uma enchente em São Sebastião do Caí, podendo a população precaver-se e evitar prejuízos maiores.

Tabela 04 - Percepção das enchentes pela população rural do Distrito da Várzea relacionadas às informações passadas local e intermunicipais entre a população

\begin{tabular}{lcc}
\hline \multicolumn{1}{c}{ Percepções coletadas } & $\mathbf{n}$ & $\mathbf{\%}$ \\
\hline Acompanha pelo noticiário/mídia & 2 & 50,0 \\
\hline Amigos em outras cidades avisam atual situação & 1 & 25,0 \\
\hline Há 12h de intervalo entre uma cidade e outra & 1 & 25,0 \\
\hline \hline Total & $\mathbf{4}$ & $\mathbf{1 0 0 , 0}$ \\
\hline
\end{tabular}

Fonte: Trabalho de Campo, 2007.

Org.: WOLLMANN, C. A., 2007.

Por fim, 1 entrevistado (25\%) colocou que há um intervalo de 12 horas da chegada de uma enchente entre uma cidade e outra. Considerando que a enchente começa no município de Vale Real, conforme relatos da Tabela 02, bem como atinge os municípios à jusante, tais como Feliz, Bom Princípio, São Sebastião do Caí e Montenegro, distantes 20 a 25 quilômetros um do outro, em média, o que levaria a enchente a gastar o mesmo tempo para atingir uma cidade e outra. Esta percepção, que também é passada entre as populações das cidades do Vale do Caí, além de ser um método de previsão de chagada das enchentes, pode fazer com que os municípios se organizem com antecedência para minimizar os prejuízos com a passagem da enchente. Também, esta informação constitui-se em uma forma de cognição ambiental, fruto da observação da vazão do Rio Caí ao longo dos inúmeros casos de enchente na história do Vale.

\section{Da população urbana}

No meio urbano de São Sebastião do Caí, especialmente nos bairros mais atingidos pelas enchentes, foram entrevistadas 35 pessoas, sendo 22 do sexo masculino $(62,9 \%)$ e 13 do sexo feminino (37,1\%). Desse total, 6 pessoas possuíam entre 20 e 35 anos de idade, correspondendo a 17,1\% do total, 13 pessoas com idade entre 36 e 50 anos (37,1\%), 9 pessoas com idade entre 51 e 65 anos $(25,8 \%)$ e 7 pessoas com idade superior a 66 anos, totalizando $20 \%$ dos entrevistados.

Dos 35 entrevistados, 20 deles $(57,1 \%)$ apontaram ser naturais de São Sebastião do Caí, contra 15 pessoas $(42,9)$, naturais de outras cidades do Rio Grande do Sul. Os municípios declarados como de nascença por estas pessoas, estão, Montenegro e São Leopoldo, com duas pessoas, cada, seguidos pelos municípios de Três de Maio, São Lourenço do Sul, Vacaria, Feliz, Santana do Livramento, Palmeira das Missões, Sobradinho, Harmonia, Santo Cristo, Veranópolis e Lajeado, com uma pessoa cada, totalizando os 15 entrevistados, que declararam residir no município há pelo menos 20 anos. 
Ainda, dos 35 entrevistados, 9 pessoas, (25,7\%), afirmaram morar no mesmo bairro em um período inferior a 20 anos, 12 pessoas residem entre 21 e 40 anos (34,3\%), 10 pessoas $(28,6 \%)$ entre 41 e 60 anos e 4 pessoas declararam morar no mesmo bairro desde o nascimento, totalizando $11,4 \%$ dos entrevistados.

O número de entrevistados em cada bairro na área urbana de São Sebastião do Caí está melhor colocado no gráfico da Figura 04.

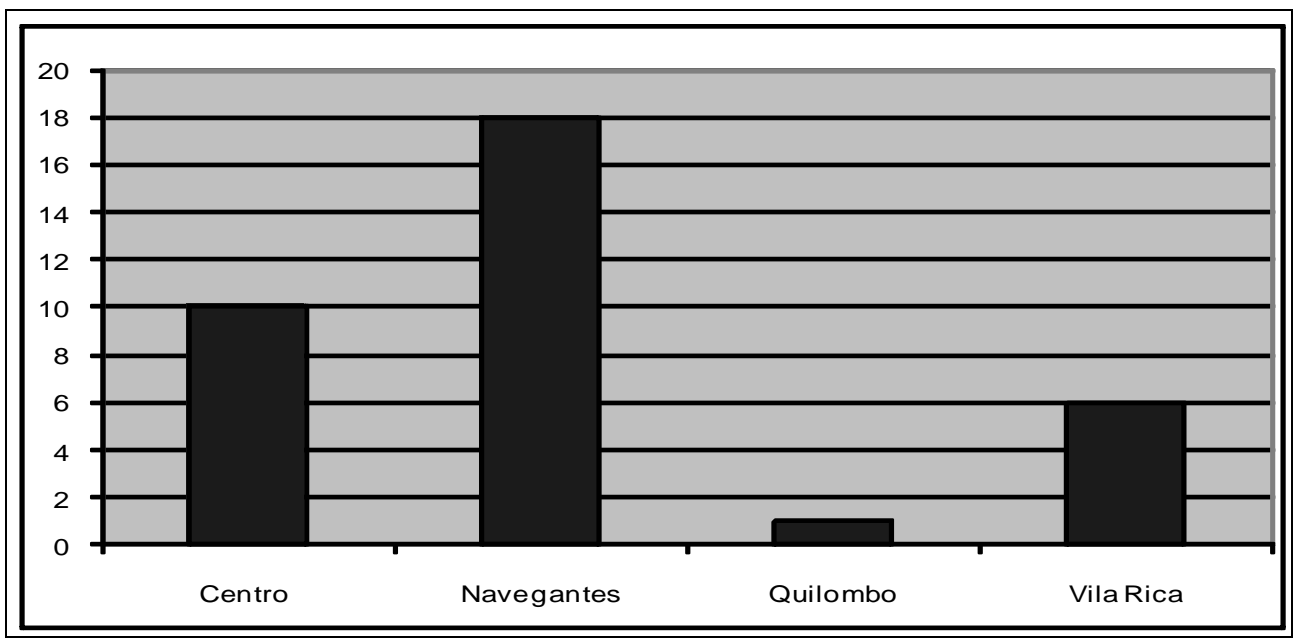

Figura 04 - Gráfico representando a quantidade de pessoas entrevistadas em cada bairro da área urbana de São Sebastião do Caí

Fonte: Trabalho de campo, maio/2007.

Org.: WOLLMANN, C. A., 2007.

Nesse sentido, optou-se por um maior número de entrevistados no bairro Navegantes, pois é o que mais é atingido por enchentes, dada sua situação topográfica e localização próxima ao rio, conforme mostrou o mapa da Figura 02. Já as atividades realizadas pelos 35 entrevistados estão melhor dispostas na Tabela 05.

De acordo com a Tabela 05, tem-se uma amostra das principais atividades exercidas pela população, estando a maioria delas ligadas ao setor de serviços e cargos públicos, bem como de aposentados, visto que o Município, mesmo localizando-se próximo a grandes centros urbanos, mostra-se calmo e é escolhido como lugar para viver após a aposentadoria.

Quando perguntado se a residência do entrevistado já havia sido atingida por alguma enchente, 30 pessoas $(85,7 \%)$ declararam já ter sua residência invadida pela água das enchentes, contra 5 pessoas $(14,3 \%)$ que não.

Dentre as maiores enchentes, a de 1982 foi citada em 16 ocasiões, perfazendo um total de 29,1\% das citações; as enchentes de 1997 foram colocadas três vezes como grandes enchentes (5,5\%); a de outubro de 2000 foi citada 29 vezes durante as entrevistas, totalizando 52,7\%; a de 2002 foi lembrada quatro vezes (7,3\%); as enchentes de 2003 foram citadas em apenas uma ocasião $(1,8 \%)$ e a de 2004 foi citada duas vezes, totalizando 3,6\% das citações. 
Tabela 05 - Atividades principais exercidas pela população urbana de São Sebastião do Caí

\begin{tabular}{lcc}
\hline \multicolumn{1}{c}{ Atividade principal } & $\mathbf{N}^{\mathbf{0}}$ de pessoas & Porcentagem (\%) \\
\hline Aposentado & 9 & 25,7 \\
\hline Dona-de-casa & 6 & 17,1 \\
\hline Pedreiro & 4 & 11,4 \\
\hline Metalúrgico & 2 & 5,7 \\
\hline Funcionário público & 2 & 5,7 \\
\hline Comerciante & 2 & 5,7 \\
\hline Criador de cavalos & 1 & 2,9 \\
\hline Pintor & 1 & 2,9 \\
\hline Costureira & 1 & 2,9 \\
\hline Bombeiro & 1 & 2,9 \\
\hline Vendedor & 1 & 2,9 \\
\hline Pescador & 1 & 2,9 \\
\hline Autônomo & 1 & 2,9 \\
\hline Professora & 1 & 2,9 \\
\hline Carteiro & 1 & 2,9 \\
\hline Doméstica & 1 & 2,9 \\
\hline \hline Total & $\mathbf{3 5}$ & $\mathbf{1 0 0 , 0}$ \\
\hline
\end{tabular}

Fonte: Trabalho de Campo, 2007.

Org.: WOLLMANN, C. A., 2007.

Ainda, 25 entrevistados (71,4\%) declararam terem tido algum tipo de prejuízo em suas residências, contra 10 pessoas $(28,6 \%)$. Os prejuízos mais citados no meio urbano estão relatados na Tabela 06.

Tabela 06 - Tipos de prejuízos mais comuns ressaltados pela população urbana de São Sebastião do Caí em casos de enchentes

\begin{tabular}{lcc}
\hline \multicolumn{1}{c}{ Prejuízo relatado } & $\mathbf{N}^{\circ}$ de citações & Porcentagem (\%) \\
\hline Móveis & 20 & 40,8 \\
\hline Barro/sujeira & 10 & 20,4 \\
\hline Eletrodomésticos & 7 & 14,3 \\
\hline Reparos e pinturas & 6 & 12,2 \\
\hline Roupas & 3 & 6,1 \\
\hline Ferramentas & 1 & 2,1 \\
\hline Mercadorias & 1 & 2,1 \\
\hline Água levou a casa & 1 & $\mathbf{2 , 1}$ \\
\hline \hline Total & $\mathbf{4 9}$ & $\mathbf{1 0 0}$ \\
\hline
\end{tabular}

Fonte: Trabalho de Campo, 2007.

Org.: WOLLMANN, C. A., 2007.

$\mathrm{Na}$ questão de número 5 (Quais os sinais que a natureza lhe dá para saber se ocorrerá ou não enchente em São Sebastião do Caí, ou como o(a) Sr (a). sabe se vai acontecer uma enchente e se ela será grande ou pequena, por exemplo?), que revelaria a real percepção ambiental e climática dos moradores 
da área urbana de São Sebastião do Caí sobre as enchentes, deixou-se que a população revelasse tantas quantas observações julgasse importante, pois foi dada liberdade de resposta, podendo a mesma pessoa indicar mais de uma observação.

Após tabuladas as observações coletadas junto à população, além de deparar-se com um número superior de percepções em relação às coletadas no meio rural, muitas delas eram novas, e as observações eram mais elaboradas e ricas em conhecimento empírico.

Ainda, pode-se perceber que as observações estendiam-se ao campo da observação do comportamento dos animais frente às enchentes. Nesse sentido, as observações foram divididas em quatro classes de percepções: observação do escoamento das águas superficiais, da dinâmica atmosférica, da comunicação entre a população intra e intermunicipal e da observação do comportamento dos animais.

Também, notou-se repetência de algumas observações com as já mencionadas pelos moradores do meio rural, principalmente no que diz respeito às observações relacionadas com o escoamento das águas superficiais, e a Tabela 07 mostra as percepções coletadas junto à população urbana.

Tabela 07 - Percepção das enchentes pela população urbana de São Sebastião do Caí relacionadas à observação do escoamento das águas superficiais

\begin{tabular}{lccc}
\hline \multicolumn{1}{c}{ Percepções coletadas } & $\mathbf{n}$ & $\mathbf{\%}$ \\
\hline A mudança do relevo muda a enchente & 7 & 26,9 \\
\hline $\begin{array}{l}\text { "Quanto mais galho e sujeira descer com a enchente, maior ela } \\
\text { vai ser" }\end{array}$ & 4 & 15,3 \\
\hline Arroios "correm para cima" & 3 & 11,5 \\
\hline A enchente vem do Arroio Forromeco & 3 & 11,5 \\
\hline As barragens ajudam a conter as enchentes & 2 & 7,7 \\
\hline $\begin{array}{l}\text { "Se subir 40-45cm/h, a enchente não chega nas casas, mas se } \\
\text { subir mais de 60cm/h, é grande" }\end{array}$ & 1 & 3,8 \\
\hline Arroio Bonito bota pra fora/ na estrada & 1 & 3,8 \\
\hline "Se a água do rio roncar, dá enchente" & 1 & 3,8 \\
\hline "Se a água baixar rápido demais, vem outra enchente logo atrás" & 1 & 3,8 \\
\hline "Se o rio estiver baixo demais, não dá enchente" & 1 & 3,8 \\
\hline "Quando o Rio Cadeia represa o Caí, dá enchente" & 1 & 3,8 \\
\hline $\begin{array}{l}\text { "Quando o rio corre só no meio, e não nas barrancas, sinal de } \\
\text { enchente" }\end{array}$ & 1 & 3,8 \\
\hline Total & $\mathbf{2 6}$ & $\mathbf{1 0 0 , 0}$ \\
\hline
\end{tabular}

Fonte: Trabalho de Campo, 2007.

Org.: WOLLMANN, C. A., 2007.

De acordo com a Tabela 07, repara-se que algumas percepções são semelhantes às colocadas pela população rural e contidas na Tabela 02, tais como "arroios correm para cima"; "Arroio Bonito bota pra fora/na estrada"; "se a água baixar rápido demais, vem outra enchente logo atrás"; "se o rio estiver baixo demais, não dá enchente" e "quando o Rio Cadeia represa o Rio Caí, dá 
enchente". Nesse sentido, a fim de se evitar repetições textuais, tais explicações já foram dadas posteriormente à Tabela 02.

Portanto, dentre as percepções que mais foram citadas em relação ao escoamento das águas superficiais, de um total de 26 está a de que "a mudança do relevo muda a enchente", com 7 observações, totalizando 26,9\%. A mudança do relevo, conforme relato pelos entrevistados, diz respeito ao aterramento e asfaltamento da RS 124, localizada na margem oposta da cidade de São Sebastião do Caí, no Rio Caí. Nesse caso, a população colocou que, com a construção da rodovia, a água não iria mais para aquele setor da várzea, aumentando o nível das enchentes em direção da cidade.

Conforme reportagens do jornal local, e confirmação in loco, durante a construção da estrada vários viadutos e bueiros foram construídos para que a água pudesse passar livremente de um lado para o outro, logo, essa percepção da população tornar-se-ia negativa.

Em segunda colocação, com 4 observações (15,3\%), foi dito que "quanto mais galho e sujeira descer junto com a enchente, maior ela vai ser". De fato, significa que a água à montante da bacia atingiu locais que antes não estavam inundados, sendo capaz de transportar galhos e lixo que porventura estavam acumulados nestas áreas. Em muitos casos, em função da forte vazão fluvial, pode arrancar árvores inteiras. Essa percepção pode se tornar uma forma de previsão quanto ao tamanho da enchente, pois pode ser observada a quantidade de galhos e lixo levados pelo rio horas antes de sua chegada.

Com três observações $(11,5 \%)$, foi colocado pelos entrevistados que "a enchente vem do Arroio Forromeco". De acordo com Wollmann (2008), que analisou a geomorfologia fluvial deste canal, observou-se que o referido arroio possui uma distância muito inferior a apresentada pelo Rio Caí (de sua nascente até a foz do Forromeco), e declividade próxima à nascente relativamente maior, bem como sua orientação norte-sul pode facilitar o escoamento da água em direção às áreas a sua jusante.

Conforme reportagens do jornal local, os estragos causados pela enchente de 1982 foram muito maior na bacia do Arroio Forromeco quando comprados com as repercussões ocorridas no alto trecho do Rio Caí. Nesse sentido, ressalta-se que gênese das enchentes não se dá apenas nas cabeceiras do Arroio Forromeco, mas em toda a Bacia Hidrográfica do Rio Caí, mas em função de uma menor distância entre a nascente e foz, o aprofundamento do vale maior associado a uma orientação norte-sul pode favorecer a chegada da água deste setor da bacia em comparação com outro setor que contém as nascentes do Rio Caí, propriamente dito.

Assim, essa população residente às margens do Arroio Forromeco pode avisar a população à jusante quais as reais condições para se prevenir de futuros danos causados pela enchente. Também, cabe ressaltar aqui que, o fato da população perceber que a enchente "vem do Forromeco" pode se dar através de um errôneo juízo de valor. A área compreendida pela bacia do Arroio Forromeco são muito mais povoadas do que as áreas do alto trecho do Rio Caí, o que confere maiores prejuízos em casos de enchente. Neste caso, a população pode inferir que a enchente inicia-se no Arroio Forromeco em função do maior número de repercussões sócio-econômicas e ambientais concentrar-se nesta área.

No decorrer da pesquisa, duas observações $(7,7 \%)$ a respeito de que "as barragens ajudam a conter as enchentes". Trata-se do sistema de transposição 
de águas da Bacia do Rio Caí para a Bacia do Rio dos Sinos para geração de energia elétrica, na qual $60 \%$ da água é utilizada nesta transposição, conforme o relatório da Secretaria Estadual do Meio Ambiente - SEMA (2006). Entretanto, sabe-se que as barragens possuem um controle significativo sobre as vazões, evitando enchentes em períodos de pluviometria extrema em locais à jusante de suas localizações.

Com uma observação (3,8\%), foi colocado que "se á água subir 40-45 centímetros por hora, a enchente não chega às casas, mas se subir mais de 60 centímetros por hora, vai ser grande". Esta percepção é, na verdade, uma observação realizada através das réguas de medições do nível do rio localizadas às suas margens na área urbana. Com isso, observou-se que quanto mais rápido a água sobe, maior será a coluna d'água que vai gerar a enchente, pois dado o intervalo de 12 horas entre uma cidade e outra, mais água estará vindo da cidade à montante, aumentando o nível da enchente.

Ressalta-se que a Defesa Civil Municipal já possui valores oficiais para classificação das enchentes quanto ao nível que atingem valores estes que não diferem do observado pela população nas réguas às margens do rio. Logo, esta observação já é levada em conta nos momentos de enchente em relação à previsão de seu crescimento.

Também em uma observação ( $3,8 \%$ do total de observações), foi declarado que se "a água do rio roncar, dá enchente". Nesse caso, o que acontece é um aumento significativo na vazão do rio, sendo que o fluxo de deslocamento da água é tão forte que pode, até mesmo, fazer barulho (roncar). De acordo com o engenheiro Frederico Kayser, funcionário da Prefeitura Municipal e que trabalha com a ocorrência de enchentes no Rio Caí desde a década de 1970, segundo ele, em comparação com a enchente de outubro de 2000, com 14,75 metros de altura, a vazão no Rio Caí chegou a valores próximos de $1.000 .000 \mathrm{~m}^{3} / \mathrm{s}$, gerando muita movimentação e barulho na água que desce pelo rio.

Por fim, uma pessoa $(3,8 \%)$ colocou que "quando o rio corre só no meio, e não nas barrancas, sinal de enchente". O que, de fato, ocorre, não apenas quando há enchente, mas o fluxo de água sempre é maior no centro do rio ou onde a profundidade é maior (leito de vazante), mas quando ocorrem enchentes, em função da maior vazão, a velocidade de fluxo no centro do rio também aumenta consideravelmente. No entanto, conforme o relato, este fluxo é percebido apenas em casos de enchente, quando está mais veloz, daí a pessoa prestar mais atenção ao rio por causa do medo provocado pela enchente.

Em relação às percepções relacionadas à observação da dinâmica atmosférica, a Tabela 08 mostra os principais relatos dos entrevistados urbanos com intuito de previsão de enchentes.

Como já era esperado, 14 pessoas afirmaram que não sabem ou que é muito difícil saber quando ocorrem enchentes, com um total de $31,8 \%$ sobre as 44 observações mencionadas, número maior comparado com o meio rural.

Assim como o ocorrido na Tabela 07, a Tabela 08 apresenta algumas observações já relatadas pela população rural da Várzea. Dentre as quais está a de que "tem que chover na serra/cabeceiras", com 12 referências (27,3\%). Isso mostra que, assim como a população rural, a população urbana também demonstra conhecimento ao dizer que a gênese da enchente está na 
precipitação que cai no topo do planalto, e não a que precipita sobre São Sebastião do Caí.

Tabela 08 - Percepção das enchentes pela população urbana de São Sebastião do Caí relacionadas à observação da dinâmica atmosférica

\begin{tabular}{lcc}
\hline \multicolumn{1}{c}{ Percepções coletadas } & $\mathbf{n}$ & $\mathbf{\%}$ \\
\hline Não sabe/muito difícil saber & 14 & 31,8 \\
\hline Tem que chover nas cabeceiras & 12 & 27,3 \\
\hline "Se chover de 3 a 5 dias sem parar, dá enchente" & 8 & 18,2 \\
\hline Dá uma enchente grande a cada 20 anos & 3 & 6,8 \\
\hline "Acontece com as enchentes de São Miguel" & 2 & 4,5 \\
\hline Acontecem no início e no fim do inverno & 1 & 2,3 \\
\hline $\begin{array}{l}\text { "Se vem chuva primeiro que o vento, sinal de muita chuva e } \\
\text { enchente; se ventar antes, é chuva rápida e passageira" }\end{array}$ & 1 & 2,3 \\
$\begin{array}{l}\text { "Se o rio está cheio e amanhece com nevoeiro sobre ele, dá } \\
\text { enchente" }\end{array}$ & 1 & 2,3 \\
\hline $\begin{array}{l}\text { "Quando cai chuva pesada e formar bolha na água, enchente na } \\
\text { certa" }\end{array}$ & 1 & 2,3 \\
\hline $\begin{array}{l}\text { "Quando as paredes da casa suam e chove vários dias, dá } \\
\text { enchente" }\end{array}$ & 1 & 2,3 \\
\hline \hline Total & $\mathbf{4 4}$ & $\mathbf{1 0 0 , 0}$ \\
\hline
\end{tabular}

Fonte: Trabalho de Campo, 2007.

Org.: WOLLMANN, C. A., 2007.

Em 8 casos $(18,2 \%)$ foi dito ser necessário chover de 3 a 5 dias para dar enchente. Conforme Wollmann (2008), em suas pesquisas envolvendo Análise Rítmica (Monteiro, 1971), nem sempre é necessário chover durante todo este período para que ocorra enchente. Na verdade, é reconhecido, empiricamente, que o tipo de tempo dominado pela presença de uma frente estacionária, que permanece vários dias sobre o Rio Grande do Sul, pode gerar enchente, dependendo da quantidade de chuva precipitada na parte alta da bacia hidrográfica.

Assim, como no meio rural, foi citado intervalo temporal entre as grandes enchentes, ou seja, "dá uma enchente grande a cada 20 anos", com 3 observações $(6,8 \%)$. De fato, no meio rural foi citado um intervalo duas vezes menor - 10 anos, entretanto o intervalo colocado no meio urbano aproxima-se mais da realidade, pois entre as maiores enchentes do Rio Caí (1982 e 2000), há um intervalo de 18 anos, aproximadamente os 20 anos descritos pelos entrevistados, que lembraram melhor o intervalo de tempo.

Isso se dá, principalmente, por estas pessoas morarem praticamente nos mesmos locais durante o tempo entre as duas enchentes, aliado ao fato de que é no meio urbano que são sentidos os maiores prejuízos; também a influência que a mídia exerce na população sobre informar as grandes enchentes, mesmo quando ocorrem casos menores. Desse modo, a população pode lembrar-se melhor dos fatos ocorridos no passado.

Em um caso $(2,3 \%)$ foi referido que as enchentes ocorrem juntamente com as "Enchentes de São Miguel". De acordo com a sazonalidade e número de enchentes mensais estudadas no item 4.2 deste capítulo, aliado às conclusões 
de Rossato; Sartori; Missio, et. al. (2003), 25\% das enchentes acontecem durante a primavera, sendo que na análise mensal, setembro e outubro concentram $12,5 \%$ das enchentes em relação ao outros meses do ano. Assim, as que ocorrem durante os dois meses citados têm, de fato, relação com as enchentes de São Miguel, mas não são as únicas a ocorrer (WOLLMANN, 2008).

Foi colocado também por um entrevistado que as enchentes "acontecem no início e fim de inverno", somando 2,3\% das citações. Ainda, de acordo com a Tabela 08, as enchentes concentram-se nos meses de inverno e início de primavera, com maior freqüência durante o mês de junho (25\%). De fato, o inverno concentra $50 \%$ das enchentes ocorridas no período, sendo $25 \%$ no mês de junho e o restante nos outros meses. No entanto, ao final do inverno têm-se os meses de setembro e outubro se destacam como os mais chuvosos na maior parte do Estado (Sartori, 1993a) e que concentram boa parte das enchentes. Esta percepção é de grande valia, pois mostra que a população tem conhecimento sobre a sazonalidade dos eventos, observando de forma regular o fluxo da água e as condições de tempo a fim de prever as enchentes com certa antecedência.

Com apenas uma referência $(2,3 \%)$, foi colocado que "se vem chuva primeiro que o vento, sinal de muita chuva e enchente; se ventar antes é chuva rápida e passageira". Na verdade, esta observação não tem comprovação científica quanto à gênese das enchentes, pois se trata se uma ligeira diferença apresentada, muitas vezes, pelo mesmo tipo de tempo determinado pela passagem frontal, que pode ou não gerar enchentes (WOLLMANN, 2008).

Também, com uma colocação $(2,3 \%)$, foi referido que "se o rio está cheio e amanhece com nevoeiro sobre ele, dá enchente". Este nevoeiro pode ser classificado como um nevoeiro de advecção, pois se forma quando a massa de ar está mais fria que a superfície sobre a qual se desloca, superfície esta que pode ser sólida ou líquida. Os nevoeiros, em geral, formam-se quando a massa de ar que está dominando contém muita umidade, e pouco antes do amanhecer, quando são registradas as menores temperaturas, é que a umidade contida no ar se condensa, formando o nevoeiro.

$\mathrm{Na}$ verdade, os nevoeiros em geral, no Rio Grande do Sul, formam-se após passagens frontais, quando ocorre o domínio da massa polar. O único nevoeiro a se formar com participação da frente polar é o nevoeiro polar pósfrontal (Sartori, 1981), dada a grande umidade deixada pela frente no Estado após sua passagem. Como se formou nevoeiro sobre o rio, conforme o relato significa que a massa de ar polar já está dominando sobre o Estado, e que a frente polar já avançou para latitudes menores, diminuindo as chances de enchente, mesmo com o nível do rio alto. A única forma de ocorrer uma enchente resume-se ao fato de que frente fria (FPA) pode recuar como frente quente e permanecer sobre o Rio Grande do Sul por alguns dias, como frente estacionária, elevando os índices pluviométricos.

Outra afirmação de um entrevistado (2,3\%) foi "quando cai chuva pesada e formar bolha na água, enchente na certa". Na verdade o que ocorre com as chuvas torrenciais, é que o pingo torna-se muito volumoso e, com a grande velocidade atingida ao cair das nuvens, ao bater sobre a água do rio, forma-se uma espécie de "buraco na água", devido ao impacto produzido, podendo sugerir a visão de uma pequena bolha na superfície ao voltar para seu estado normal; também provoca a propagação de pequenas ondas. 
Acontece que, durante uma chuva torrencial, que pode estar associada à passagem de uma frente fria de deslocamento rápido (FFDR), podendo originar enchente, são incontáveis de pingos de chuva, relativamente grandes, que batem na superfície da água. Este processo combinado gera muita movimentação na superfície do rio, sugerindo a formação de inúmeras bolhas.

Nesse sentido, a população deve ter associado a forte chuva que formou "bolhas" sobre a água à chuva que causa enchentes, pois, se a passagem de uma FFDR for responsável por formar chuvas torrenciais, ao encontrar a barreira orográfica formada pelo rebordo do Planalto da Bacia do Paraná, as chuvas serão intensificadas no topo do planalto, podendo gerar enchentes.

Por fim, foi referido por um entrevistado, totalizando 2,3\% das 44 percepções coletadas, que "quando as paredes da casa suam e chove vários dias, sinal de enchente". Na verdade, esta expressão contém duas previsões: uma delas refere-se à previsão do tempo a curto prazo, ligada ao fato das paredes da casa suarem, já comentadas por Sartori (2000), pois especialmente no inverno antes da chegada de uma frente polar, dominavam baixas temperaturas com o domínio da MPA. Durante a fase pré-frontal, com altas temperaturas do ar e declínio da umidade relativa, dentro das residências, em geral, a temperatura permanece mais baixa do que a registrada externamente, e na superfície de pisos, móveis e paredes, geralmente, com revestimentos mais frios, a temperatura é mais baixa ainda, e a umidade do ar em contato com esta superfície acaba condensando, dando a impressão de que a parede esta "suando".

Com a chegada da frente polar, conforme a observação coletada, se esta permanecer por vários dias sobre o território sul-rio-grandense, como frente estacionária, pode levar ao surgimento de enchentes. Assim, o fato das paredes "suarem" apenas indica a chegada de chuva nas próximas horas ou dias, mas é a permanência do sistema frontal que pode provocar enchentes.

Já a Tabela 09 mostra a percepção relacionada às informações passadas entre a população local e regional sobre as enchentes e suas repercussões, obtidas no meio urbano de São Sebastião do Caí.

Tabela 09 - Percepção das enchentes pela população urbana de São Sebastião do Caí relacionadas à comunicação entre a população local e regional

\begin{tabular}{lcc}
\hline \multicolumn{1}{c}{ Percepções coletadas } & $\mathbf{n}$ & $\mathbf{\%}$ \\
\hline Amigos em outras cidades avisam atual situação & 2 & 66,7 \\
\hline Acompanha pelo noticiário/mídia & 1 & 33,3 \\
\hline Total & $\mathbf{3}$ & $\mathbf{1 0 0 , 0}$ \\
\hline
\end{tabular}

Fonte: Trabalho de Campo, 2007.

Org.: WOLLMANN, C. A., 2007.

De acordo com a Tabela 09, assim como foi relatado pelos moradores do distrito rural de Várzea (TABELA 04), os moradores da área urbana também se comunicam e são avisados por moradores de áreas à montante sobre a real situação das enchentes em suas localidades antes de atingir o meio urbano caiense. A população de São Sebastião do Caí já utiliza este sistema de informação para previsão de desastres causados pela passagem das enchentes, não sendo necessária sua explicação a fim de evitar repetições textuais. 
Ao final, a Tabela 10 mostra as percepções em relação às enchentes do Rio Caí relacionadas à observação do comportamento dos animais, e que não foram obtidas nas entrevistas realizadas no meio rural.

Tabela 10 - Percepção das enchentes pela população urbana de São Sebastião do Caí relacionadas à observação do comportamento dos animais

\begin{tabular}{lcc}
\hline \multicolumn{1}{c}{ Percepções coletadas } & $\mathbf{n}$ & $\mathbf{\%}$ \\
\hline "Os sapos coaxam diferente, abafado" & 2 & 100,0 \\
\hline \hline Total & $\mathbf{2}$ & $\mathbf{1 0 0 , 0}$ \\
\hline
\end{tabular}

Fonte: Trabalho de Campo, 2007.

Org.: WOLLMANN, C. A., 2007.

Inesperadamente, apenas no meio urbano é que se ouviu falar em mudanças no comportamento dos animais com intuito de previsão de enchentes. Nesse sentido, apenas duas pessoas, totalizando $100 \%$ das observações, relataram que antes da chegada de uma enchente "os sapos coaxam diferente, abafado". Na verdade, não se trata de uma observação do comportamento do animal, mas apenas de ouvir as mudanças nos sons emitidos por eles. De acordo com o relatório da SEMA (2006), o "sapo-da-enchente", como é vulgarmente conhecido, é um anuro da família Leptodactylidae, da espécie Odontophrynus americanus, e vive em ambientes úmidos, bem como em matas e campos secos e úmidos, especialmente em áreas alagadiças, como as várzeas de rios.

Em entrevista à bióloga e ecóloga da Universidade Luterana do Brasil (ULBRA) de Canoas/RS, Jessica Monghilhott Marques, os anuros possuem o seu sistema fonético muito ligado às condições ambientais, principalmente no que se refere à umidade presente no ar. Isso se dá, principalmente, porque os sapos necessitam de ambiente com muita água para reprodução, e no Rio Grande do Sul, segundo a bióloga, não há uma época de reprodução dos anuros, eles reproduzem-se a cada chuva. Segundo ela, como no reino animal são os machos que necessitam conquistar as fêmeas para o acasalamento, os sapos conquistam suas fêmeas através do coaxar antes do início da chuva, logo o sapo que tiver o melhor coaxar ganha a fêmea, e o acasalamento ocorre antes e durante a chuva, pois assim, os ovos fecundados são levados para mais longe pela água da chuva, ampliando o território genético do casal de sapos.

Nesse sentido, em períodos de enchente, cuja alta umidade atmosférica é fato (WOLLMANN, op. cit.), essa condição ambiental pode levar os sapos a terem um coaxado diferente, explicou a bióloga. O coaxado pode ser mais intenso quanto maior for a umidade atmosférica registrada e quanto mais tempo permanecer chovendo, pois a propagação do som se faz de forma diferente quando o ar está mais úmido (Sartori, 2000), logo, pode ser ouvido um coaxar diferente, "abafado" conforme relataram as duas pessoas na entrevista.

Assim, a observação dos anuros pode ser utilizada não como forma de previsão da ocorrência das enchentes, mas sim de previsão da quantidade de chuva que por ventura ainda poderá precipitar, elevando o nível da enchente, uma vez que enquanto durarem os coaxados dos sapos, a chuva permanecerá em São Sebastião do Caí, bem como em toda a Bacia Hidrográfica do Rio Caí, segundo a percepção popular. 


\section{CONCLUSÕES}

Já no levantamento da percepção ambiental e climática da população como forma de prevenção de enchentes no Município, contrariamente ao que se pensava a priori, a população urbana possui uma percepção muito mais aguçada do que a rural quanto à ocorrência de enchentes, ressaltando até a observação do comportamento de animais, o que não foi descrito no meio rural.

As percepções coletadas foram classificadas em basicamente 4 grupos: observação do escoamento das águas superficiais, da dinâmica atmosférica, das informações locais e intermunicipais e do comportamento dos animais. Nesse sentido, apenas as informações relacionadas à observação do escoamento das águas é que de fato podem ser utilizadas como forma de previsão de enchentes para São Sebastião do Caí, mas com apenas algumas horas de antecedência, pois as mudanças são observadas quando já está ocorrendo enchente nas cabeceiras da bacia hidrográfica.

Com relação às informações locais e intermunicipais, estas já são utilizadas como forma de avisos da população que reside em toda a bacia hidrográfica, porém devem ser intensificadas e associadas às do escoamento superficial das águas, a fim de evitar maiores prejuízos com a chegada de enchentes.

A previsão de enchentes pela observação da dinâmica atmosférica, mostrou-se muito difícil, conforme foi relatado pelos entrevistados, pois a circulação atmosférica que resulta em enchente não é específica de uma estação e pode ocorrer em qualquer época do ano. Entretanto, alguns casos ainda não especificamente estudados pelas ciências atmosféricas, podem estar relacionados a bloqueios no deslocamento de massas de ar e correntes de ar da atmosfera superior.

Quanto ao comportamento animal, o coaxar dos sapos é observado no momento em que está acontecendo a enchente, não se tornando uma forma de previsão e prevenção de desastres naturais.

Assim, esse estudo contribui não só para as indagações do autor, mas também para o rol de pesquisas da Climatologia Geográfica brasileira e sul-riograndense, servindo, portanto, como fonte teórico-metodológica que possa motivar investigações futuras.

\section{REFERÊNCIAS BIBLIOGRÁFICAS}

BUSS, M. D.; FURTADO, S. M. A.; SCHEIBE, L. F. "É, ninguém escapa do rio..." Geografia de uma catástrofe natural. Geosul. v. 15, n. 29, p. 55-78, Jan./Jun., 2000.

CLAUSSE, R. Meteorologia e folclore. Revista O Correio. Rio de Janeiro. [s./v.], n. 10-11, p. 49-52, 1973.

COLLOT, M. Pontos de vista sobre a percepção das paisagens. Boletim de Geografia Teorética. Rio Claro. v. 20, n. 39, p. 21-32, 1990.

COQUE, R. Geomorfología. Madrid: Alianza, 1984. 
MACHADO, L. M. C. P. Paisagem valorizada - A Serra do Mar como espaço e como lugar. In.: OLIVEIRA, L de; DEL RIO, V. (Org.). Percepção ambiental a experiência brasileira. São Paulo: Studio Nobel; São Carlos: Ed. da UFSCar, 1996. p. 96-119.

MARIANTE, H. M. Santa Bárbara, São Jerônimo! Meteorologia e astronomia populares no RS. Porto Alegre: Martins Livreiro, 1985.

MEGALE, J. F. (Org.).; FERNANDES, F. (Coord.). Max Sorre - Geografia. São Paulo: Ática, 1984.

MINISTÉRIO DAS CIDADES. Plano Diretor Participativo. Brasília, DF, 2001. Disponível em: <www.cidades.gov.br>. Acesso em: 01 ago. 2007.

MONTEIRO, C. A. F. Teoria e clima urbano. São Paulo: Instituo de Geografia/USP, 1976. 181p. (Série Teses e Monografias, 25).

MONTEIRO, C.A. F. Análise rítmica em climatologia - problemas da atualidade climática em São Paulo e achegas para um programa de trabalho. Revista IGUSP. São Paulo. [s./v.], [s./n.], p. 1-21, 1971.

MOURÃO, R. R. F. Vai chover no fim de semana? São Leopoldo: UNISINOS, 2003.

OLIVEIRA, L de; DEL RIO, V. (Org.). Percepção ambiental - a experiência brasileira. São Paulo: Studio Nobel; São Carlos: Ed. da UFSCar, 1996.

ROSSATO, P. S.; SARTORI, M. G. B.; MISSIO, L. R. et al. A gênese das "Enchentes de São Miguel" na região central do Rio Grande do Sul. In: CONGRESSO BRASILEIRO DE AGROMETEOROLOGIA, 13., 2003, Santa Maria. Anais... Santa Maria: UFSM, 2003. 1 CD-ROM.

SÁNCHEZ, S. U. Percepción ambiental y impactos urbanos. Revista Geográfica. [s./v.], n. 31, p. 61-68, 1991.

SARTORI, M. G. B. A percepção do tempo e a cognição ambiental do homem rural do Rio Grande do Sul. In: SIMPÓSIO NACIONAL SOBRE GEOGRAFIA, PERCEPÇÃO E COGNIÇÃO DO MEIO AMBIENTE, 1., 2005, Londrina. Anais... Londrina: UEL, 2005. 1 CD-ROM.

SARTORI, M. G. B. A dinâmica do clima do Rio Grande do Sul: indução empírica e conhecimento científico. Revista Terra Livre, São Paulo, v. 1, n. 20, p. 2749, jan./jul. 2003.

SARTORI, M. G. B. Clima e percepção. 2000. 488p. Tese (Doutorado em Geografia) - Universidade de São Paulo, São Paulo, 2000. 2 v.

SECRETARIA ESTADUAL DE MEIO AMBIENTE. Departamento de Recursos Hídricos. 1a Etapa do Plano de Bacia do Rio Caí: Consolidação do conhecimento sobre recursos hídricos e enquadramento dos recursos hídricos 
superficiais - Relatório temático A2, Diagnóstico da disponibilidade hídrica. Porto Alegre, 2006a. 186p.

TUAN, Y-F. Topofilia. Tradução prefácio e notas: Lívia de Oliveira. São Paulo: DIFEL, [1980].

WHYTE, A. V. T. La perception de I'environnement: lignes directrices méthodologiques pour les études sur le terrain. 7. ed. Paris: UNESCO, 1978.

WOLLMANN, C. A. A gênese climática das enchentes na Bacia Hidrográfica do Rio Caí. 2008. 115p. Trabalho de Graduação (Graduação em Geografia Bacharelado) - Universidade Federal de Santa Maria, 2008.

WOLLMANN, C. A.; SARTORI, M. G. B.; RUOSO, D.; et. al. A nebulosidade como fator condicionante à percepção da pluviometria anual pela população rural e urbana de São Sebastião do Caí/RS. In: SEMINÁRIO LATINOAMERICANO DE GEOGRAFIA FÍSICA, 4., 2006, Maringá. Anais... Maringá: UEM, 2006. 1 CDROM. 
